\title{
Identifikasi Kandungan Berbahaya Jajanan Anak Sekolah Dasar SDN A dan SDN B Kota Samarinda Tahun 2018
}

\author{
La Anton ${ }^{1}$, Sri Evi New Yearsi ${ }^{2}$, Muhammad Habibi ${ }^{3}$ \\ antonriskin08@gmail.com, evi_nypw@yahoo.co.id, Universitas Widya Gama Mahakam, Indonesia ${ }^{1,2}$ \\ mhabibi@umkt.ac.id, Universitas Muhammadiyah Kalimantan Timur, Indonesia ${ }^{3}$
}

\begin{abstract}
Abstrak
Latar Belakang:

Makanan jajanan menurut Food and Agriculture Organization (FAO) didefisinikan sebagai makanan dan minuman yang dipersiapkan dan dijual oleh pedagang kaki lima di jalanan dan di tempat- tempat keramaian umum lain yang langsung dimakan atau dikonsumsi tanpa pengolahan atau persiapan lebih lanjut. Sedangkan menurut Depkes RI (2013) makanan jajanan merupakan makanan dan minuman yang bisa langsung di konsumsi dan dapat dibeli dari penjual makanan, yang diproduksi oleh penjual tersebut atau yang diproduksi oleh orang lain, tanpa diolah lagi.
\end{abstract}

Tujuan :

Untuk mengetahui kualitas jajanan anak Sekolah Dasar SDN A dan SDN B Kecamatan Sungai Pinang wilayah kerja Puskemas Remaja Samarinda tahun 2018.

Metode Penelitian:

Penelitian ini menggunakan rancangan Pra-Eksperimen The One Shot Case Study. Teknik pengambilan sampel adalah purposive random sampling. Sampel pada penelitian adalah makanan jajanan siomay, cireng, pentol, mie basah, kerupuk dan saos yang di jual di lingkungan SDN A dan SDN B Kecamatan Sungai Pinang Dalam.

Hasil :

Hasil penelitian, setelah dilakukan pengamatan dari 12 sampel makanan jajanan secara kualitas fisik, yaitu dari warna, rasa, bau dan benda asing, didapatkan hasil makanan jajanan tersebut aman untuk dikonsumsi. Namun hasil uji kualitas kimia pada makanan jajanan tersebut didapatkan $67 \%$ sampel yang mengandung formalin dan $8 \%$ sampel mengandung boraks. Hasil uji kualitas biologi didapatkan 11 sampel jajanan tercemar bakteri coliform, namun terdapat 2 sampel jajanan yang melewati syarat mutu SNI-3788-2009 tentang batas maksimum cemaran mikroba dalam makanan.

\section{Kesimpulan:}

Dari 12 sampel dari 6 jenis makanan jajanan yang sama, tidak ditemukan ciri-ciri sampel yang mengandung formalin dan boraks. yang teridentifikasi positif mengandung formalin 1 sampel siomay, 2 sampel cireng, 2 sampel pentol, 1 sampel mie basah, dan 2 sampel krupuk. Berdasarkan hasil uji Laboratorium kandung boraks pada 12 sampel dari 6 jenis makanan jajanan yang sama, terdapat 1 jenis sampel makanan jajanan yang teridentifikasi mengandung boraks, yaitu 1 sampel pentol. Cemaran kandungan bakteri Coliform ditemukan 11 sampel makanan jajanan positif tercemar bakteri Coliform dan terdapat 2 sampel makanan jajanan mie basah dengan cemaran coliform TBUD (tidak bisa untuk dihitung).

Kata kunci: Makanan Jajanan, Kualitas Fisik, Kualitas Kimia, Kualitas Biologi.

\section{Abstract}

Background:

Snack food according to the Food and Agriculture Organization (FAO) is defined as food and drink prepared and sold by street vendors on the streets and other public places that are directly eaten or consumed without further processing or preparation. Meanwhile, according to the Indonesian Ministry of Health (2013), hawker food is food and drinks that can be directly consumed and can be purchased from food vendors, which are produced by these sellers or produced by others, without being processed again.

Objectives:

To find out the quality of snacks for elementary school children of A and B in Sungai Pinang District, the area of Samarinda Youth Health Center in 2018.

Research Metodes:

This research uses the One-Shot Case Study Pre-Experiment design. The sampling technique is purposive random sampling. The samples in this study are snacks siomay, cireng, pentol, wet noodles, crackers and sauces which are sold in the SDN A and SDN B environments of Sungai Pinang Dalam District. 


\section{Results:}

The results of the study, after observing from 12 samples of snacks in physical quality, namely from the colour, taste, smell and foreign objects, obtained the results of these snacks are safe for consumption. However, the results of chemical quality tests on these snacks obtained 67\% of samples containing formaldehyde and $8 \%$ of samples containing borax. The results of the biological quality test found 11 samples of snacks contaminated with coliform bacteria, but there were 2 samples of snacks that passed SNI-3788-2009 quality requirements about the maximum limit of microbial contamination in food.

\section{Conclusion:}

Of the 12 samples from 6 types of food that are the same, no characteristics of the samples containing formalin and borax were found. which was identified as positively containing 1 formalin siomay sample, 2 sample slabs, 2 pentol samples, 1 wet noodle sample, and 2 cracker samples. Based on the results of Borax bladder Laboratory tests on 12 samples from 6 types of food that are the same, there is 1 type of food that is identified containing borax, namely 1 sample of pentol. Coliform bacteria contamination found 11 samples of positive snacks contaminated with Coliform bacteria and there were 2 samples of wet noodle snacks with coliform contamination (cannot be counted).

Keywords: Food Snacks, Physical Quality, Chemical Quality, Biological Quality.

\section{DOI}

Received

Accepted

Published
: http://dx.doi.org/10.24903/kujkm.v5i1.828

\section{: February 2019}

: $\quad$ April 2019

: June 2019

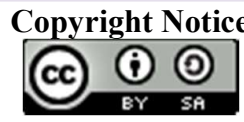

This work is licensed under Creative Commons Attribution 4.0 International License

P-ISSN: 2477-1880 E-ISSN: 2502-6623

\section{PENDAHULUAN}

Makanan jajanan menurut Food and Agriculture Organizatian (FAO) adalah makanan yang dipersiapkan dan dijual oleh pedagang kaki lima di jalanan dan tempat- tempat keramaian umum, yang langsung dimakan atau dikonsumsi tanpa pengolahan atau persiapan lebih lanjut. Sedangkan makanan jajanan menurut Depkes RI (2013) adalah makanan dan minuman yang bisa langsung di konsumsi dan dapat dibeli dari penjual makanan, yang diproduksi oleh penjual terseut atau yang diproduksi oleh orang lain, tanpa di olah lagi. Istilah makanan jajanan tidak jauh dari istilah junk food, fast food, dan street food karena istilah tersebut merupakan bagian dari istilah makanan jajanan. Seluruh lapisan masyarakat sangat menyukai jajanan pinggir jalan, terkhususnya anak sekolah. Setiap jam istirahat sekolah anak sekolah selalu mengkonsumsi jajanan yang telah tersedia di sekolah, baik itu yang digoreng maupun tidak.

Jajanan anak sekolah akhir-akhir ini sedang mendapat sorotan khusus, kualitas jajanan anak sekolah masih belum terjamin keamanannya dari penjamah maupun bahan tambahan pangannya. Pelaku usaha 
yang tidak mementingkan perlindungan terhadap konsumen serta didukung tidak adanya pengawasan pada penjamah makanan. Sehingga sangat berisiko tercemar oleh mikroorganisme atau bahan kimia yang dapat mengganggu kesehatan serta tumbuh kembang anak, baik jangka pendek maupun jangka panjang. Zat yang terkandung dalam jajanan sekolah dapat menimbulkan reaksi akut pada tubuh, yaitu berupa batuk, diare, alergi, kesulitan buang air besar atau bahkan menimbulkan keracunan (Adriana dan Wijatmadi, 2013).

Pangan yang terdapat Coliform, berarti bahan pangan tersebut telah tercemar oleh kotoran manusia. Bahan pangan ini kemungkinan juga mengandung bakteri-bakteri patogen yang berasal dari kotoran tersebut. Cemaran oleh bakteri Coliform tidak dikehendaki, baik ditinjau dari nilai estetika, kebersihan, maupun kemungkinan terjadi infeksi yang berbahaya. Jika didalam $750 \mathrm{~mL}$ sampel terdapat $>1100$ bakteri Coliform, memungkinkan terjadinya penyakit yang pada keadaan tertentu dapat mengalahkan mekanisme pertahanan tubuh, antara lain dapat menyebabkan diare, dan infeksiinfeksi lainnya. Salah satu anggota kelompok Coliform adalah Escherichia Coli. Karena Escherichia coli adalah bakteri Coliform yang ada pada kotoran manusia, maka Escherichia coli sering disebut sebagai Coliform fecal. Kualitas mikrobiologi makanan jajanan dapat ditentukan berdasarkan nilai MPN Coliform, nilai MPN Coliform fekal, dan jumlah koloni Escherichia coli. Berdasarkan Standarisasi Nasional Indonesia (SNI) 7388-2009 tentang batas maksimum cemaran mikroba dalam makanan yaitu $1 \times 10^{6}$ koloni/gram.

Berdasarkan data pengawasan Pangan Jajanan Anak Sekolah (PJAS) yang dilakukan oleh BPOM RI pada tahun 2015 menunjukan bahwa sebasar 40\% pangan jajanan anak sekolah tidak memenuhi syarat karena mengandung bahan kimia seperti rhodamin B, siklamas, methanil yellow, boraks dan formalin, serta teridentifikasi cemaran mikrobiologi, sehingga makanan jajanan anak sekolah tersebut tidak layak untuk di konsumsi karena tingkat pencemarannya melewati ambang batas yang telah ditetapkan (BPOM RI, 2016).

Hasil uji terhadap sampel PJAS oleh BPOM Samarinda tahun 2016 sebanyak 308 sampel diperoleh dari 32 Sekolah Dasar (SD) di Kalimantan Timur. Sebanyak 133 sampel (43\%) memenuhi syarat dan 175 sampel (57\%) tidak memenuhi syarat. Parameter uji yang tidak memenuhi syarat antara lain Rhodamin B sebanyak 6 sampel ditemukan pada sampel kerupuk, Boraks sebanyak 15 sampel pada sampel kerupuk, Nitrit 
sebanyak 1 sampel pada jenis kudapan, Benzoat sebanyak 4 sampel masingmasing 2 sampel untuk jenis kudapan dan mie, dan sisanya sebanyak 107 sampel adalah TMS mutu cemaran mikroba (BPOM Samarinda, 2016).

Menurut data Sistem Informasi Kesehatan Daerah (SIKDA) tahun 2015 Kecamata Sungai Pinang Dalam Samarinda, masuk dalam 3 besar penderita diare setelah Kelurahan Harapan Baru dan Kelurahan Sempaja Timur, yaitu 636 penderita (SIKDA,2015). Di Puskesmas Remaja Kecamatan Sungai Pinang, kasus penderita penyakit diare pada tahun 2015 tercatat 636 penderita, di tahun 2016 sebanyak 338 penderita dan pada tahun 2017 tercatat sebanyak 312 penderita penyakit diare. Penyakit diare pada tahun 2015 hingga tahun 2017 masuk dalam daftar prioritas pengendalian penyakit bulanan Puskesmas Remaja.

Kecamatan Sungai Pinang Dalam masuk dalam wilayah kerja Puskesmas Remaja, yang dimana wilayah kerjanya memiliki Sembilan Sekolah Dasar (SD). Dari sembilan SD tersebut, yang telah diobservasi yaitu SD 001 dengan jumlah siswa 323 siswa dan SD 007 dengan jumlah siswa 1.216 siswa, dan sebagian besar Siswa yang ada di Sekolah Dasar tersebut bertempat tinggal di Kelurahan Bandara dan Kelurahan Temindung Permai. Dari hasil observasi dua SD tersebut, ditemukan adanya penjual pentol goreng, bakso, cireng dan tahu goreng yang berjualan di depan Sekolah dan jalan raya dengan tidak menutup dagangannya yang menyebabkan makanan jajanan tersebut terpapar oleh polutan.

Terkait hal tersebut menjadikan peneliti memilih wilayah kerja Puskesmas Remaja sebagai lokasi penelitian. Ini dilakukan berdasarkan hasil pemeriksaan jajanan anak sekolah, masih adanya pengolah jajanan yang merugikan masyarakat khususnya anak sekolah yang mengkonsumsinya. Masalah yang dikhawatirkan jika tidak terus dilakukan pengawasan maka penjual jajanan yang tidak memenuhi syarat kesehatan akan terus menjamur.

\section{METODE PENELITIAN}

Penelitian ini menggunakan rancangan penelitian Pra- Eksperimen The One Shot Case Study (Studi kasus bentuk tunggal), yaitu Sebuah eksperimen yang dilakukan tanpa adanya kelompok pembanding dan juga tanpa adanya tes awal, yang bertujuan untuk mengetahui efek dari perlakuan yang diberikan pada kelompok tanpa mengindahkan pengaruh faktor yang lain. Penelitian ini dilaksanakan di wilayah kerja Puskesmas Remaja Samarinda SDN A (SDN 001) dan SDN B (SDN 007) Sungai Pinang Dalam, pada bulan Januari - Oktober 
2018. Sampel yang digunakan di ambil dari 2 Sekolah Dasar wilayah kerja Puskesmas Remaja Kec. Sungai pinang dalam, yaitu SDN A 6 sampel di antaranya siomay, cireng, pentol, mie basah, kerupuk dan saos, dan SDN B 6 sampel di antaranya siomay, cireng, pentol, mie basah, kerupuk dan saos. Jumlah sampel yang diamati adalah 12 sampel. Sampel berasal dari pedagang jajanan yang ada di lingkungan SDN A dan SDN B Kecamatan Sungai Pinang Dalam. Sampel diambil dan kemudian dibawa kelaboratorium untuk dilakukan uji laboratorium. Data dapat langsung di peroleh setelah melakukan uji lapangan dan uji laboratorium. Uji lapangan dilakukan dengan cara turun langsung kelapangan penelitian untuk memastikan dan melihat secara langsung A dan SDN B Kecamatan Sungai Pinang Dalam. Sedangkan uji laboratorium adalah melakukan pemeriksaan dengan menggunakan alat-alat yang tersedia di laboratorium. Sampel jajanan diberikan perlakuan untuk menguji ada atau tidaknya penggunaan boraks, formalin dan cemaran coliform pada jajanan tersebut.

\section{HASIL PENELITIAN}

Tabel 1. Hasil Pemeriksaan Kualitas Fisik Pada Makanan Jajanan di SDN Wilayah Kerja

\begin{tabular}{|c|c|c|c|c|c|c|c|c|c|c|}
\hline \multirow{4}{*}{$\begin{array}{l}\text { Kode } \\
\text { Sampel }\end{array}$} & \multicolumn{8}{|c|}{ Pengamatan } & & \\
\hline & \multirow{3}{*}{$\begin{array}{c}\text { Jenis } \\
\text { Sampel }\end{array}$} & \multirow{3}{*}{ Metode } & \multicolumn{8}{|c|}{ Parameter uji } \\
\hline & & & \multicolumn{2}{|c|}{ Warna } & \multicolumn{2}{|c|}{ Rasa } & \multicolumn{2}{|c|}{ Bau } & \multicolumn{2}{|c|}{ Benda asing } \\
\hline & & & Alami & $\begin{array}{r}\text { Tidak } \\
\text { Alami }\end{array}$ & Alami & $\begin{array}{r}\text { Tidak } \\
\text { Alami }\end{array}$ & Alami & $\begin{array}{l}\text { Tidak } \\
\text { Alami }\end{array}$ & Ada & $\begin{array}{l}\text { Tidak } \\
\text { Ada }\end{array}$ \\
\hline A1 & Siomay & & 1 & 0 & 1 & 0 & 1 & 0 & 0 & 1 \\
\hline $\mathrm{A} 2$ & Cireng & & 1 & 0 & 1 & 0 & 1 & 0 & 0 & 1 \\
\hline A3 & Pentol & & 1 & 0 & 1 & 0 & 1 & 0 & 0 & 1 \\
\hline A4 & Mie basah & & 1 & 0 & 1 & 0 & 1 & 0 & 0 & 1 \\
\hline A5 & Kerupuk & & 1 & 0 & 1 & 0 & 1 & 0 & 0 & 1 \\
\hline A6 & Saos & Observasi & 1 & 0 & 1 & 0 & 1 & 0 & 0 & 1 \\
\hline B1 & Siomay & lapangan & 1 & 0 & 1 & 0 & 1 & 0 & 0 & 1 \\
\hline B2 & Cireng & & 1 & 0 & 1 & 0 & 1 & 0 & 0 & 1 \\
\hline B3 & Pentol & & 1 & 0 & 1 & 0 & 1 & 0 & 0 & 1 \\
\hline B4 & Mie basah & & 1 & 0 & 1 & 0 & 1 & 0 & 0 & 1 \\
\hline B5 & Kerupuk & & 1 & 0 & 1 & 0 & 1 & 0 & 0 & 1 \\
\hline B6 & Saos & & 1 & 0 & 1 & 0 & 1 & 0 & 0 & 1 \\
\hline
\end{tabular}

Tabel 2. Hasil Pemeriksaan Kandungan Formalin pada Makanan Jajanan di SDN Wilayah Kerja Puskesmas Remaja Kecamatan Sungai Pinang Dalam Tahun 2018

\section{Pengamatan}

\begin{tabular}{cllccc}
$\begin{array}{c}\text { Kode } \\
\text { sampel }\end{array}$ & $\begin{array}{c}\text { Jenis } \\
\text { Sampel }\end{array}$ & Parameter & Metode & $\begin{array}{c}\text { Hasil } \\
\text { Uji } \\
+\end{array}$ & - \\
\hline A1 & Siomay & & 0 & 1 \\
A2 & Cireng & & 1 & 0 \\
A3 & Pentol & & 1 & 0 \\
A4 & Mie & basah & & 1 & 0 \\
A5 & Kerupuk & & & 1 & 0 \\
A6 & Saos & Formalin & Pereaksi & 0 & 1 \\
B1 & Siomay & & Nash & 0 \\
B2 & Cireng & & & 1 & 0 \\
B3 & Pentol & & 1 & 0 \\
B4 & Mie & basah & & 0 & \\
B5 & Kerupuk & & 1 & 0 \\
B6 & Saos & & 0 & 1 \\
\hline & & & $\mathbf{8}$ & $\mathbf{4}$ \\
\hline
\end{tabular}

Tabel 3. Hasil Pemeriksaan Kandungan Boraks Pada Makanan Jajanan di SDN Wilayah Kerja Puskesmas Remaja Kecamatan Sungai Pinang Dalam Tahun 2018

$$
\text { Pengamatan }
$$

\begin{tabular}{llllll} 
No & $\begin{array}{l}\text { Jenis } \\
\text { Sampel }\end{array}$ & Parameter & Metode & $\begin{array}{l}\text { Hjil } \\
\text { Uji } \\
+\end{array}$ & - \\
\hline A1 & Siomay & & \multirow{2}{*}{ Uji } & 0 & 1 \\
A2 & Cireng & Boraks & Nyala & 0 & 1 \\
A3 & Pentol & & & 1 & 0
\end{tabular}




\begin{tabular}{llll} 
A4 & $\begin{array}{l}\text { Mie } \\
\text { basah }\end{array}$ & 0 & 1 \\
A5 & Kerupuk & 0 & 1 \\
A6 & Saos & 0 & 1 \\
B1 & Siomay & 0 & 1 \\
B2 Cireng & 0 & 1 \\
B3 Pentol & 0 & 1 \\
B4 Mie & 0 & 1 \\
B5 & Kerupuk & & \\
12 Saos & 0 & 1 \\
\hline Total & 0 & 1 \\
\hline \multicolumn{2}{l}{}
\end{tabular}

Tabel 4. Hasil Pemeriksaan Cemaran Coliform Pada Makanan Jajanan di SDN Wilayah kerja Puskesmas Remaja Kecamatan Sungai Pinang Dalam Tahun 2018

\begin{tabular}{|c|c|c|c|c|c|c|}
\hline \multirow[b]{2}{*}{$\begin{array}{c}\text { Kode } \\
\text { Sampel }\end{array}$} & \multirow[b]{2}{*}{$\begin{array}{c}\text { Jenis } \\
\text { Sampel }\end{array}$} & \multirow[b]{2}{*}{$\begin{array}{c}\text { Syarat } \\
\text { Mutu }\end{array}$} & \multirow{2}{*}{\multicolumn{2}{|c|}{$\begin{array}{l}\text { Pengamatan } \\
\text { Para Meter } \\
\text { Uji }\end{array}$}} & \multicolumn{2}{|c|}{ Hasil Uji } \\
\hline & & & & & $\begin{array}{c}\text { Memenuhi } \\
\text { Syarat }\end{array}$ & $\begin{array}{c}\text { Tidak } \\
\text { Memenuhi } \\
\text { Syarat }\end{array}$ \\
\hline $1 \mathrm{~A}$ & Siomay & & $13 \times 10^{4}$ & & Ya & - \\
\hline $2 \mathrm{~A}$ & Cireng & & $1 \times 10^{4}$ & & $\mathrm{Ya}$ & - \\
\hline $3 \mathrm{~A}$ & Pentol & & $2 \times 10^{4}$ & & Ya & - \\
\hline $4 \mathrm{~A}$ & Mie basah & & TBUD & & - & Tidak \\
\hline $5 \mathrm{~A}$ & Kerupuk & & $17 \times 10^{4}$ & & $\mathrm{Ya}$ & - \\
\hline $6 \mathrm{~A}$ & Saos & $1 \mathrm{X} 10^{6}$ & $5 \times 10^{4}$ & Kuantitatif & Ya & - \\
\hline $1 \mathrm{~B}$ & Siomay & koloni/gram & $7 \times 10^{4}$ & Uji KIT & $\mathrm{Ya}$ & - \\
\hline $2 B$ & Cireng & & $5 \times 10^{4}$ & & Ya & - \\
\hline $3 B$ & Pentol & & $2 \times 10^{4}$ & & Ya & - \\
\hline $4 \mathrm{~B}$ & Mie basah & & TBUD & & - & Tidak \\
\hline $5 \mathrm{~B}$ & Kerupuk & & 0 & & Ya & - \\
\hline $6 \mathrm{~B}$ & Saos & & $63 \times 10^{4}$ & & $\mathrm{Ya}$ & - \\
\hline
\end{tabular}

\section{PEMBAHASAN}

\section{Identifikasi Kualitas Fisik}

Berdasarkan tabel 4.6 di atas, dari hasil observasi dan pengamatan lapangan, pada 12 sampel dari 6 jenis makanan jajanan tersebut tidak di temukan adanya ciri-ciri sampel yang mengandung formalin ataupun boraks seperti halnya di lihat dari warna, sampel makanan jajanan tersebut tidak ditemukan adanya sampel yang berwarna mencolok keputihan dan mengkilap, dari rasa jika dimakan jajanan tersebut tidak ditemukan adanya rasa getir di lidah dan tidak juga bertekstur kenyal, dari baunya tidak pula ditemukan adanya bau yang menyengat tajam sehingga menghilangkan bau alami dari makanan jajanan tersebut, serta tidak ditemukan adanya benda asing seperti rambut, plastik, logam, isi staples, lidi, sisa potongan kuku, dan benda-benda asing lainnya yang tercampur pada makanan jajanan tersebut. Namun secara kasat mata kualitas fisik makanan jajanan sulit untuk di identifikasi kandungan formalin ataupun boraksnya, hal ini disebabkan kadar formalin dan boraks yang dugunakan dengan jumlah yang sedikit dalam makanan jajanan, sehingga perlu adanya uji laboratorium untuk memastikan ada tidaknya kandungan formalin dan boraks pada makanan jajanan tersebut.

Seperti halnya penelitian yang dilakukan oleh Ida Mudzkirah pada tahun 2016 di Kantin UIN Alauddin Makasar yaitu dari 12 sampel (100\%) makanan jajanan secara kualitas fisik dinyatakan baik, hal ini berdasarkan observasi dan pemeriksaan lebih lanjut yang dilakukan di laboratorium Kedokteran dan Ilmu Kesehatan UIN Alauddin Makasar.

Berdasarkan hasil pengujian makanan jajanan oleh Badan POM Semarang tahun 2002-2004 dari 20 sampel makanan jajanan dinyatakan aman secara fisik. Hal ini di lihat dari warna, rasa dan bau (Wisnu Cahyadi,2006). Sementara 
hasil uji produk pangan Balai Besar POM

Semarang tahun 2005 menemukan 29,74\% sampel mengandung bahan tambahan pangan berbahaya. Kandungan bahan berbahaya pada jajanan anak sekolah sekarang juga memperhatinkan, dimana dari 86 sampel yang diuji secara fisik 40 sampel tidak memenuhi syarat dan mengandung bahan berbahaya seperti boraks, formalin dan zat pewarna (FMIPA, 2006).

\section{Identifikasi Kualitas Kimia}

Berdasarkan hasil uji sampel tersebut menggambarkan bahwa 12 sampel dari 6 jenis makanan jajanan yang sama ditemukan ada 8 sampel yang mengandung formalin ditandai dengan munculnya warna kuning pucat pada destilat yang sudah dihomogenkan dengan reagen, sedangkan 4 sampel tidak mengandung formalin serta tidak mengalami perubahan warna. Adapun 8 sampel tersebut yang positif mengandung formalin adalah siomay 1 sampel, cireng 2 sampel, pentol 2 sampel, mie basah 1 sampel, dan kerupuk 2 sampel.

Sebelumnya Peneliti telah melakukan percobaan pertama uji kandungan formalin pada makanan jajanan tersebut di Laboratorium FKM UWGM, uji formalin yang dilakukan menggunakan metode spot test yaitu tes kit FMR (formalin main reagent), dengan melakukan pengulangan sebanyak 3 kali pada setiap sampel yang sama dari 12 sampel makanan jajanan tersebut, hasilnyapun relatif sama dengan hasil uji kandungan formalin yang dilakukan di Laboratorium FMIPA UNMUL, sampel makanan jajanan yang positif mengandung formalin setelah dilakukan dengan menambahkan cairan (reagent A dan B) sebanyak 4 tetes pada bahan makanan, maka terjadilah perubahan yaitu warna ungu dan yang negatif di tandai dengan warna bening pada sampel makanan jajanan tersebut. Namun metode ini masih kualitatif sehingga Peneliti mengirimkan sampek ke Laboratorium FMIPA UNMUL sebagai uji penegas sehingga tidak terjadi keragu-raguan.

Berdasarkan hasil observasi dan wawancara yang dilakukan oleh peneliti di lapangan, ada sebagian pedagang yang tidak mengetahui bahaya menggunakan bahan tambahan makanan dalam hal ini formalin, mereka beranggapan bahwa jika bahan kimia tersebut dicampur dalam bahan makanan, maka daya tahan simpan makanan jajanan tersebut akan lebih lama dan tidak mudah rusak. Seperti halnya pada pedagang cireng dan pentol, dalam setiap memproduksi bahan, mereka selalu memproduksi stok bahan dalam jumlah banyak yang di simpan di dalam kulkas, hingga bisa sampai penjualan 2 hingga 3 minggu lamanya, hal ini tergantung pada kondisi pemasaran atau penjualan, Mereka 
selalu membawa stok cireng dan pentol mentah dengan jumlah yang banyak setiap harinya yang di simpan di dalam kantong plastik dalam keadaan beku, jika tidak habis terjual pada hari itu maka cireng dan pentol tersebut dimasukan kembali ke dalam frezter, sehingga mereka tidak mengalami kerugian yang besar. Pada penjual bakso (pentol, mie basah, kerupuk dan siomay), pedagang tersebut tidak tahu menahu adanya campuran bahan kimia formalin dalam dagangannya, sebab pedagang tersebut hanya menjual dagangan orang lain. Mereka di beri upah berdasarkan hasil penjualan dagangan pada hari itu juga. Adapun jika dagangannya tidak habis terjual, maka Mereka harus berjualan keliling di pemukiman masyarakat serta tempat keramaian lainnya hingga malam hari, dan kondisisinyapun tergantung pelanggang yang membeli, kadang habis terjual dan terkadangpun tidak, sehingga bakso tersebut di bawa pulang dan dikembalikan ke pemiliknya. Sedangkan pada pedagang bakso yang lainnya mie basah yang digunakan untuk dagangannya yaitu mie dalam kemasan, adapun alasan penggunaan mie dalam kemasan dikarenakan jika membeli mie yang diproduksi sendiri, takutnya ada campuran bahan kimia seperti formalin dan boraks dan hal ini berbahanya bagi kesehatan.
Dari hasil observasi dan wawancara diatas menggambarkan bahwa kurangnya pengetahuan para pedagang terhadap bahaya penggunaan bahan tambahan formalin dalam makanan, sehingga para pedagang tersebut berasumsi dengan menggunakan bahan tambahan formalin maka jajanan yang dibuat dapat bertahan 2 hingga 3 minggu lamanya, dengan begitu mereka akan mendapatkan keuntungan yang lebih banyak. Seperti halnya pada penelitian yang dilakukan Wulan (2015) di Kota Makassar menunjukkan bahwa dari 30 sampel bakso yang diambil dari pedagang bakso yang menetap di Kecamatan Panakukang terdapat 4 sampel bakso yang dinyatakan positif menggunakan formalin. Potensi munculnya perilaku penambahan formalin dalam proses produksi bakso karena pedagang bakso diasumsikan memiliki kecenderungan untuk mengabaikan peraturan-peraturan yang terkait dengan pengolahan bahan pangan, termasuk pengolahan bahan pangan asal hewan seperti daging sapi. Asumsi tersebut muncul karena adanya orientasi ekonomis berupa target pencapaian keuntungan usaha dengan memberikan kepuasan konsumen melalui berbagai cara yang tidak dibenarkan. Kondisi lingkungan sosial (profil) merupakan faktor-faktor yang dinilai berpotensi memberikan kontribusi terhadap munculnya kasus penggunaan 
formalin dalam hasil olahan bahan pangan asal hewan seperti bakso. Kondisi lingkungan sosial biasanya membuat seseorang berfikir tentang masa depan dan membuat pilihan tentang bagaimana bertindak untuk mendapatkan target keuntungan usaha yang optimal.

Formalin yang seharusnya dipergunakan sebagai pengawet mayat atau pengawet di bidang industri ternyata disalahgunakan oleh produsen di bidang industri makanan. Biasanya hal ini sering ditemukan dalam industri rumahan karena mereka tidak terdaftar dan tidak perlu mendapat izin dari Balai Besar Pengawasan Obat dan Makanan (BPOM) setempat. Alasan pedagang menambahkan formalin ke dalam makanan adalah karena kepentingan ekonomi. Alasan ekonomi di sini berarti agar pedagang tidak mengalami kerugian bila barang dagangan mereka tidak habis terjual dalam sehari. Selain itu, kurangnya informasi tentang bahaya formalin, rendahnya tingkat kesadaran kesehatan masyarakat, serta harga formalin yang sangat murah dan mudahnya diperoleh merupakan faktor-faktor penyebab penyalahgunaan formalin sebagai pengawet dalam makanan (Edi, 2011).

Walaupun daya awetnya sangat luar biasa, formalin dilarang digunakan pada makanan, seperti halnya yang ditegaskan dalam Petaruran Menteri Kesehatan No.
722/1988, Peraturan Menteri Kesehatan No. 472/1996 tentang pengamanan bahan berbahaya bagi kesehatan, UU No. 7/1996 tentang pangan, Peraturan Menteri Kesehatan No. 1168/Menkes/PER/X/1999 tentang pangan, UU No. 8/1999 tentang perlindungan konsumen, keputusan Menteri Perindustrian dan Perdagangan No. $254 / 2000$ tentang tata niaga inpor dan peredaran bahan berbahaya tertentu, Peraturan Pemerintah No. 28/2004 tentang keamanan, mutu dan gizi pangan dan peraturan Kepala Badan Pengawasan Obat dan Makanan RI No. 36/2013 tentang batas maksimum penggunaan bahan tambahan pangan pengawet.

Dampak formalin apabila terisap bisa menyebabkan iritasi kepala serta keluar air mata, dan pusing. Apabila terminum atau termakan karena tercampur dalam makanan, maka mulut, tenggorokan dan perut terasa terbakar, sakit menelan, mual, muntah, dan diare, kemungkinan terjadi pendarahan, sakit perut yang hebat, sakit kepala, hipotensi (tekanan darah rendah), kejang, tidak sadar hingga koma, bisa menyebabkan kematian. Absorpsi toksikan melalui saluran cerna adalah toksikan yang masuk ke dalam saluran cerna dimana toksikan akan menuju lambung yang merupakan tempat penyerapan penting, lalu akan terikat dalam plasma dan diangkut yang kemudian akan 
diserap dari usus dengan sistem transport carrier (Kurniawati, 2011).

\section{Identifikasi Kandungan Boraks}

Hasil uji boraks yang dilakukan di Laboratorium FMIPA UNMUL dengan uji nyala menggunakan pereaksi asam sulfat pekat dan metanol, menunjukkan bahwa 12 sampel dari 6 jenis makanan jajanan terdapat 1 sampel yang di uji dinyatakan positif mengandung boraks yaitu pada pentol dan 11 sampel dari 6 jenis makanan jajanan lainnya dinyatakan negatif mengandung boraks. Hal ini terlihat pada uji nyala yang hanya 1 sampel makanan jajanan yang menimbulkan nyala hijau. Ini membuktikan bahwa makanan jajanan yang beredar lingkungan SDN A dan SDN B Wilayah kerja Puskesmas Remaja Kecamatan Sungai Pinang Dalam dapat dinyatakan aman untuk dikonsumsi, namun perlu adanya pengawasan lebih lanjut dari pihak setempat, sehingga di kemudian hari tidak lagi ditemukan adanya makanan jajanan yang menggunakan bahan pengawet boraks.

Sebelumnya Peneliti juga telah melakukan percobaan uji kandungan boraks di Laboratorium FKM UWGM pada jenis sampel makanan jajanan yang sama. Uji yang dilakukan dengan menggunakan metode uji warna dengan kertas turmerik dan melakukan 3 kali pengulangan dengan sampel makanan jajanan yang sama, hasilnya pun relatif sama seperti uji boraks yang dilakukan di Laboratorium FMIPA UNMUL. Hal ini dilakukan karena uji boraks dengan metode uji warna kertas turmerik masih kualitatif, sehingga peneliti melakukan uji penegasan di Laboratorium FMIPA UNMUL dengan metode nyala api, agar menghilangkan rasa keragu- raguan dalam penelitian ini.

Berdasarkan hasil observasi dan wawancara yang dilakukan oleh peneliti di lapangan, sebagian besar para pedagang memiliki pengetahuan yang baik mengenai boraks dan dampaknya bagi kesehatan. Adapun 1 sampel pentol yang di identifikasi mengandung boraks, Pedang tersebut tidak tahu-menahu mengenai penggunaan boraks pada pentol yang di jualnya, sebab pedagang tersebut hanya menjual dagangan orang lain dan di upah berdasarkan hasil penjualan hari itu juga.

Dalam penelitian yang dilakukan oleh Suntaka pada tahun 2014 di Kota Bitung membuktikan bahwa dari hasil pemeriksaan kandungan boraks pada 32 sampel dengan reaksi reagen untuk boraks, terdapat 7 sampel bakso $(21,9 \%)$ positif mengandung boraks dengan tingkat perubahan warna kertas yang berbeda satu sama lainnya, hal ini karena para pedagang telah mengetahui bahaya kesehatan dari penggunaan boraks dalam makanan, sehingga penggunaan boraks dalam bakso berbeda tiap sampelnya dan bahkan banyak sampel bakso yang tidak teridentifikasi 
boraks. Seperti halnya penelitian yang dilakukan oleh peneliti di lingkungan SDN A dan SDN B Wilayah kerja Puskesmas Remaja, ditemukan bahwa rata-rata pedagang makanan jajanan yang ada di lingkungan SD tersebut telah tahu- menahu mengenai bahaya penggunaan boraks dalam makanan, sehingga dalam hasil penelitian tersebut hanya ditemukan 1 sampel makanan jajanan yang mengandung boraks. Adanya penggunaan boraks dalam makanan, bisa jadi karena faktor perbedaan nama dan bahasa. Menurut Nurkholidah (2011) besarnya jumlah responden yang tidak mengetahui boraks dan bahayanya disebabkan karena faktor bahasa. Dalam istilah domestik boraks dikenal dengan nama bleng, pijer ataupun sebagai pengenyal.

Boraks merupakan racun bagi semua sel. Pengaruhnya terhadap organ tubuh tergantung konsentrasi yang dicapai dalam organ tubuh. Karena kadar tertinggi tercapai pada waktu diekskresi maka ginjal merupakan organ yang paling terpengaruh dibandingkan dengan organ yang lain. Dosis tertinggi yaitu $10-20 \mathrm{gr} / \mathrm{kg}$ berat badan orang dewasa dan $5 \mathrm{gr} / \mathrm{kg}$ berat badan anak-anak akan menyebabkan keracunan bahkan kematian. Sedangkan dosis terendah yaitu dibawah $10-20 \mathrm{gr} / \mathrm{kg}$ berat badan orang dewasa dan kurang dari $5 \mathrm{gr} / \mathrm{kg}$ berat badan anak-anak, (BPOM RI No. HK. 00.05.4.1745. dalam widayat
2011). Namun penggunaan boraks dalam makanan tidak diperbolehkan, seperti halnya yang ditegaskan dalam Peraturan Menteri Kesehatan RI No.722/1988 tentang bahan tambahan pangan, dan ditegaskan kembali oleh peraturan BPOM RI No.36/2013 tentang batas maksimum penggunaan bahan tambahan pangan.

Identifikasi Kualitas Biologi terhadap Cemaran Coliform

Identifikasi cemaran coliform pada sampel makanan jajanan ini dilakukan di UPTD Lobotorium Kesehatan Hewan dan Kesehatan Masyarakat Veteriner. Berdasarkan hasil uji yang dilakukan di Laboratorium tersebut menggambarkan bahwa 12 sampel dari 6 jenis makanan jajanan di SDN A dan SDN B Wilayah kerja Puskesmas Remaja Kecamatan Sungai Pinang Dalam yang dijadikan sebagai sampel dalam pemeriksaan cemaran coliform, terdapat 11 sampel makanan jajanan yang positif teridentifikasi tercemar coliform. Namun dari 11 sampel tersebut terdapat 2 sampel makanan jajanan yang jumlah cemaran bakteri coliformnya melebihi syarat mutu SNI-7388-2009 (1x10 $\quad$ kolono/gram $)$ tentang batas maksimum cemaran mikroba dalam makanan, yaitu pada ke-2 sampel mie basah dengan jumlah cemaran coliformnya TBUD (tidak bisa untuk dihitung) koloni/gram. Namun terdapat 1 
sampel makanan jajanan yang tidak sama sekali terkontaminasi oleh bakteri yaitu pada 1 sampel kerupuk 0 koloni/gram. Adanya bakteri Coliform di dalam makanan menunjukkan kemungkinan adanya mikroba yang bersifat enteropatogenik dan toksigenik yang berbahaya bagi kesehatan (Purbowarsito, 2011).

$\begin{array}{rrr}\text { Terdeteksi } & \text { adanya cemaran } \\ \text { coliform pada makanan jajanan }\end{array}$
dikarenakan kurangnya perhatian penjaja pada kebersihan. Berdasarkan pengamatan, para penjaja menjajakan makanan jajanannya di area luar sekolah. Area luar sekolah merupakan jalan umum yang sering di lewati oleh kendaraan bermotor, sehingga hal ini dapat memicu adanya kontaminasi udara dengan makanan jajanan yang dijajakan tersebut.

Dari hasil observasi dan pengamatan yang dilakukan oleh peneliti di lingkungan SDN A dan SDN B Wilayah kerja Puskesmas Remaja Kecamatan Sungai Pinang Dalam, terlihat jelas para pedangang makanan jajanan tersebut sebagian besar ditemukan makanan jajanan yang dijajakan tidak ditutup dengan plastik ataupun tutupan lainnya seperti halnya penjual pentol goreng dan cireng, setelah pentol dan cireng tersebut di goreng, jajanan tersebut diangkat dan kemudian dijajakan di tempat yang sudah disediakan sambil menunggu adanya pembeli hingga pentol dan cireng menjadi dingin, dan saos sambalnya pun dibiarkan terbuka tanpa tutupan, pedagangnya pun tidak mencuci tangan saat menjajakan cireng dan pentol tersebut, mereka hanya menyediakan kain lap untuk membersihkan tangannya.

Pada penjual siomay ditemukan kerupuk siomay yang di tumpuk di atas keranjang yang tidak menggunakan penutup, gunting atau pisau pemotong tahu dan pentol tidak di cuci sebelum digunakan, alas atau piring yang digunakan pun tidak di bersihkan atau di cuci terlebih dulu sebelum digunakan dan dibiarkan di atas meja atau gerobak dengan posisi terbuka tanpa tutup, dan terlihat mereka tidak menyediakan air untuk mencuci tangannya sebelum menyiapkan jajanan tersebut, namun mereka hanya menyediakan kain lap buat menggosok dan membersihkan kedua tangannya.

Pada penjual bakso ditemukan pula mie basah bersama bungkusan sasa (penyedap rasa) dan daun seledri yang di dalam istalasi rombong gerobak namun tidak tertutup dan bahkan pengambilan mienya ada yang menggunakan tangan tanpa menggunakan sendok penjepit atau kaos tangan. Mereka juga menyediakan kain lap yang di simpan dan di gantung di samping rombong gerobaknya yang sekalikali digunakan untuk mengeringkan kedua tangannya sebelum menyiapkan 
jajanannya. Hal ini yang menyebabkan adanya potensi kontaminasi cemaran bakteri melalui penjamah jajanan dan udara. Kondisi istalasi rombong gerobaknya tempat penyimpanan mie basahnya terlihat lembab dan sedikit berair dengan keadaan tutupannya sebagian terbuka, sehingga bisa menjadi pemicu tumbuh dan berkembangnya bakteri di dalam istalasi tersebut. Adapun jika jajanan tidak habis terjual di sekolah tersebut, maka Mereka berjualan keliling di pemukiman masyarakat dan tempat keramain lainnya hingga malam hari, itupun terkadang dagangannya tidak habis terjual, sehingga dagangannya tersebut di bawa pulang ke rumah untuk di simpan kembali ke dalam pembekuan.

Berdasarkan hasil observasi dan wawancara diatas menggambarkan bahwa rata- rata para pedagang makanan jajanan yang ada di lingkungan SDN tersebut tidak menutup makanan jajanannya pada saat dijajakan, dan para pedagangnya tersebut memiliki tingkat pengetahuan yang rendah terhadap pentingnya menjaga kebersihan disaat menjajakan makanannya, sehingga sebagian besar makanan jajanannya tercemar oleh bakteri coliform. Seperti halnya pada penelitian Riris Lindiawati Puspitasari (2013) Fakultas Sains dan Teknologi Universitas Al Azhar Indonesia, ditemukan adanya kandungan coliform pada makanan jajanan anak Sekolah Dasar, pada sampel batagor, siomay, dan mie basah, ketiga sampel ini dinyatakan positif tercemar kandungan coliform. Sampel batagor yang dijajakan tidak diletakkan dalam wadah khusus secara tertutup. Setelah di goreng, sampel batagor didiamkan di tempat terbuka untuk di jual, sehingga jajanan tersebut tercemar oleh udara, hal tersebut terjadi karena kurangnya pengetahuan penjama makanan jajanan terhadap kebersihan dalam menjajakan makanan jajanannya.

Pada penelitian Aditia Lasinrang (2015) ditemukan adanya kandungan bakteri coliform pada makanan jajanan yang dijual di Kampus II UIN Alauddin Makasar, pada sampel batagor terdapat cemaran $\quad 1.100$ Coliform/gram, pada sampel siomay 1.100 coliform/gram, dan pada sampel bakso pada pengambilan pertama ditemukan 1.100 coliform/gram, hal ini menunjukan makanan jajanan tersebut tidak layak untuk di konsumsi karena tidak memenuhi syarat Badan Standarisasi Nasional (BSN) dan SNI7388-2009 yaitu batas maksimum nilai MPN coliform $=10$ coliform/gram.

\section{KESIMPULAN}

1. Dari hasil observasi dan pengamatan yang dilakukan di SDN tersebut, 12 sampel dari 6 jenis makanan jajanan yang sama, tidak ditemukan ciri-ciri sampel yang mengandung formalin dan boraks seperti halnya di lihat dari 
warna, tidak ditemukan adanya sampel makanan jajanan yang berwarna mencolok keputihan dan mengkilap, dari rasa jika dimakan jajanan tersebut tidak ditemukan adanya rasa getir di lidah dan tidak juga bertekstur kenyal, dari baunya tidak pula ditemukan adanya bau yang menyengat tajam sehingga menghilangkan bau alami dari makanan jajanan tersebut, serta tidak ditemukan adanya benda asing yang tercampur pada makanan jajanan tersebut, sehingga dapat dipastikan secara kualitas fisik jajanan tersebut layak untuk di konsumsi.

2. Hasil uji Laboratorium kandungan formalin pada makanan jajanan di kedua SDN tersebut, 12 sampel dari 6 jenis makanan jajanan yang sama yang teridentifikasi positif mengandung formalin, yaitu 1 sampel siomay, 2 sampel cireng, 2 sampel pentol, 1 sampel mie basah, dan 2 sampel krupuk. Berdasarkan hasil uji Laboratorium kandung boraks pada 12 sampel dari 6 jenis makanan jajanan yang sama, terdapat 1 jenis sampel makanan jajanan yang teridentifikasi mengandung boraks, yaitu 1 sampel pentol.

3. Cemaran kandungan bakteri Coliform pada makanan jajanan yang dijual di lingkungan SDN A dan SDN B
Kecamatan Sungai Pinang

Dalam,12.

4. sampel dari 6 jenis makanan jajanan yang sama, ditemukan 11 sampel makanan jajanan positif tercemar bakteri Coliform. Namun, dari 11 sampel tersebut terdapat 2 sampel makanan jajanan denga jenis yang sama yang melewati syarat mutu SNI7388-2009 (1x10 $0^{6} \mathrm{koloni} /$ gram $)$ yaitu pada sampel mie basah dengan cemaran coliform TBUD (tidak bisa untuk dihitung). Sehingga jajanan tersebut tidak layak untuk di konsumsi.

\section{REFERENSI}

Aditia, Lasinrang. (2015). Uji Kualitas Mikrobiologis Pada Makanan Jajanan di Kampus II Universitas Islam Negri (UIN) Alauddin Makasar: Vol. 3 No. 2. Hal. 119-123. Badan Pengawasan Obat dan Makanan. (2013). Data Tahun 2013 Bahan Berbahaya Pada Panganan Jajanan Anak Sekolah. Samarinda.

Badan Pengawasan Obat dan Makan . 2013. Data Tahun 2013 Batas Maksimum Penggunaan Bahan Tambahan Pangan Pengawet. Republik Indonesia.

Badan Pengawasan Obat dan Makanan, (2014). Data Tahun 2014 Bahan Berbahaya Pada Panganan Jajanan Anak Sekolah. Samarinda.

Badan Pengawasan Obat dan Makanan, (2015). Data Tahun 2015 Bahan Berbahaya Pada Panganan Jajanan Anak Sekolah. Samarinda. 
Badan Pengawasan Obat dan Makanan. (2016). Tentang Bahaya Formalin. Jakarta.

Badan Pengawasan Obat dan Makanan. (2016). Tentang Bahaya Boraks. Jakarta

Badan Pengawasan Obat dan Makanan. (2016). Tentang Bahaya Methanil Yellow. Jakarta.

Badan Pengawasan Obat dan Makanan. (2016). Tentang Rhodamin B. Jakarta.

Badan Pengawasan Obat dan Makanan. (2016). Tentang Bahan Tambah Pangan. Jakarta

Cahyadi, Wisnu. (2008). Bahan Tambahan Pangan: Jakarta: PT Bumi Aksara.

Direktorat Bina Gizi Dan Kesehatan Ibu Dan Anak Kementrian Kesehatan. (2011). Tentang Pedoman Keamanan Pangan Anak Sekolah Dasar: Jakarta.

Departemen Kesehatan RI. 2003. Keputusan Menteri Kesehatan RI Nomor 942/Menkes/SK/VII/2003. Tentang Pedoman Persyaratan Hygiene Sanitasi Makanan Jajanan. Jakarta.

FMIPA. Seminar Nasional Kimia Pangan. 2006. Semarang: Universitas Diponegoro.

Fakultas Kesehatan Masyarakat. Universitas Sumatera Utara.

Hidayat. 2010. Pengantar Ilmu Keperawatan Anak. Ed. 1. Salembang Medika. Jakarta.

Kurniawati. 2011. Analisis Bahaya Kandungan Bahan Tambahan Pangan Pada Jajanan Pinggiran Kota Bandung. Skripsi. Fakultas Kesehatan Masyarakat. Universitas Pasundan.

Keputusan Menteri Kesehatan Republik Indonesia
No.42/MENKES/SK/VII/2003,

tentang definisi makanan jajanan

Keputusan Menteri Kesehatan Republik Indonesia Nomor 1098/Menkes/VII/2003 tentang persyaratan hygiene sanitasi rumah makan dan restoran.

Mulia, M, Ricki. (2005). Kesehatan Lingkungan. Yogyakarta : Graha Ilmu.

Mansauda, L.R. Karlah. Dkk. (2014). Tentang Analisis Cemaran Bakteri Coliform pada saus Tomat, Jajanan Bakso Tusuk yang Beredar di Manado: Program Studi Farmasi FMIP UNSRAT Manado: Vol. 3 No.

2. Mei 2014. ISSN. 2302-2493.

Notoatmodjo, Soekidjo. (2010). Metode Penelitian Kesehatan. Jakarta: Rineka Cipta.

Notoatmodjo. 2010. Ilmu Kesehatan Masyarakat. Jakarta. Rineka Cipta.

Peraturan Badan Pengawasan Obat dan Makanan. (2012). Tentang Pangan.

Peraturan Menteri Kesehatan No. 492/Menkes/SK/VII/2003, tentang makanan jajanan.

Peraturan Mentri Kesehatan Repoblik Indonesia No. 75/Menkes/SK/2013. Tentang Angka Kecukupan Gizi.

Purnawijayanti, A, Hiasinta. (2005). Sanitasi, Higiene, dan Keselamatan Kerja Dalam Pengolahan Makanan. Yogyakarta: Kanisius.

Ratnawati. 2010. Moment Perang Orang dengan Pretasi Belajar Siswa kelas IV SDN Tulusrejo III Kecamatan Lowok Waru Kota Malang.

Sabri, Lukis, Hastono, Priyo, Susanto. (2014). Statistik Kesehatan : Jakarta : Rajawali Pers.

Sari. Siti Ardina. 2014. Perbedaan kadar formalin pada tahu yang di jual di Pasar Pusat Kota dengan Pinggiran 
Kota Padang. Skripsi. Padang.

Fakultas Kedokteran . Universitas Andalas

Slamet, Juli, Soemirat. 2007. Kesehatan Lingkungan. Yogyakarta: Gadjah Mada

Sukemi, Sayidi. (2010). Angka Kecukupan Gizi Yang Dianjurkan Bagi Bangsa Indonesia. Fakultas Kesehatan Masyarakat. Universitas Widya Gama Mahakam Samarinda

Sugiyono. 2011. Metode Penelitian Kuantitatif Kualitatif dan $R \& D$. Bandung. Alfabeta.

Sofi A(2008). Mempelajari Kandungan secara Kualitatif dan Kuantitatif Senyawa Formalin pada Mie basah di beberapa Pasar Tradisional Kota Bandung. Tugas akhir yang tidak dipublikasikan. Fakultas Teknik. Universitas Pasundan, Bandung.

Soetjiningsih. 2010. Buku Ajar 1. Tumbuh Kembang Anak dan Remaja. Gizi untuk Tumbuh Kembang Anak. Ed. 1. Jakarta. Sgung Seto.

Tjiptaningdyat. 2010. Studi Keamanan Pangan pada Tahu Putih yang beredar di Pasar Sidoarjo (kajian dari kandungan formalin). Surabaya. Fakultas Pertanian. Universitas Dr. Soetomo Surabaya

Undang-undang Nomor 36 Tahun 2009, pasal 111 ayat (1) tentang standar makanan dan minuman yang sehat

Utama dkk. 2013. Buku Ajar 1. Tumbuh Kembang Anak dan Remaja. Gizi Untuk Tumbuh Kembang Anak. Ed. 1. Jakarta. Sagung Seto.

Winarno, F, G. (2004). Keamanan Pangan Jilid 1. Bogor: M Briopress

Winarno, F, G. (2007). Keamanan Pangan Jilid 3. Bogor: M Briopress

Widayat (2013). Analisis \& Aspek Kesehatan Bahan Tambahan
Pangan. Jakarta: Penerbit Bumi Aksara.

Widianti dan Ristianti. 2004. Analisi kualitas bakteri coloform pada depo air minum isi ulang di Kota Singaraja Bali. Jurnal Ekologi Kesehatan. (3)1: 64-73

Widya Karya Nasional Pangan dan Gizi (WNPG). 2006. Angka Kecukupan Gizi dan Acuan Label Gizi. Jakarta. 17-19 mei 2006

Wisnu Cahyadi. 2006. Analisis dan Aspek Kesehatan Bahan Tambahan Pangan. Jakarta: PT Bumi Aksara

Yulianti. 2012. Awas! Bahaya Dibalik Lezatnya Makanan. Ed. Pertama. 9293, CV. Andi Offset. Yogyakarta.

Zuraidah (2007). Perilaku penjaja Pangan Jajanan Anak Sekolah Terhadap Keamanan Pangan di Jakarta dan Sukabumi. Jurnal Gizi dan Pangan. Volume 5(3): 148-157. Departemen Gizi Masyarakat. Fakultas Ekologi Manusia. Institut Pertanian Bogor. Bogor. 